\title{
Effect of Management Practices on Growth and Productivity of Chip Bud Raised Sugarcane (Saccharum offcinarum L.)
}

\author{
S. Thiruvarassan*, G. Manickam and M. Jayachandran \\ Sugarcane Research Station, Tamil Nadu Agricultural University, Cuddalore 607001, Tamil Nadu, India
}

\begin{abstract}
Field experiments were carried out during early seasons of 2014 to 2016 (main and ratoon crops) at Sugarcane Research Station, Cuddalore to ascertain the effect of intra-row spacings, doses of NPK, of bio- inoculants in combination with the practice of topping under conventional method of flooding irrigation for chip bud raised sugarcane seedlings. The adoption of $30 \mathrm{~cm}$ intra-row spacings $+100 \%$ dose of NPK + topping treatment registered significantly maximum number of tillers per hectare, however, $45 \mathrm{~cm}$ intra- row spacings $+100 \%$ recommended dose of NPK + topping had maximum values for, yield parameters viz., cane length (289 and 282 $\mathrm{cm})$, cane girth $(2.79$ and $2.66 \mathrm{~cm})$ individual cane weight $(2.06$ and $1.97 \mathrm{~kg})$ and millable canes $(1,27,600$ and $1,23,600)$, cane yield (140.43 and 129.94 tha $\left.^{-1}\right)$ and sugar yield (16.86 and 15.67 tha $\left.^{-1}\right)$.
\end{abstract}

Keywords: Chip bud seedlings, spacings, NPK, topping and bio-inoculants

\section{Introduction}

The system of Sustainable Sugarcane Initiative (SSI) offers a new dimension to obtain sustained productivity of sugarcane through effective utilization of varied input resources viz., land, water, fertilizers along with lesser quantity of planting materials compared to higher quantum of seed cane requirement with setts planting. For producing healthier chip bud seedlings huge investment with advance technical knowledge is required (Kabir et al. 2003). In Tamil Nadu, sizable farmers are in marginal category and they cannot afford the initial input cost instead they prefer to adopt conventional setts planting with 80 or $90 \mathrm{~cm}$ row spacings. Despite higher cost involvement, in areas having ample ground water supply, farmers are reluctant to adopt drip irrigation/ fertigation compared to conventional flooding irrigation and fertilizer broadcasting. In chip bud raised seedlings, the magnitude of tiller, millable cane and cane productivity are higher, which could not be achieved without adequate crop nourishment. Hence, the addition of biofertilizer component is highly beneficial in a long run because of their ability to supply essential nutrients and growth promoting substances. Under such situations it is of prime significance to formulate sugarcane production package that would cater optimal intra-row spacings for chip bud seedlings with appropriate dose of NPK and topping under conventional flooding irrigation. Considering the above facts the present investigation was conducted.

*Corresponding author: (Email: thiruvarassan@rediffmail.com) 


\section{Materials and Methods}

Field experimentations were carried out at Sugarcane Research Station,Cuddalore during 2014 to 2016. The first year crop was raised during 2014-15 and it was subsequently ratooned during 2015-16. The experimental sandy loam soil $\mathrm{pH} 7.7$ is low in available nitrogen $\left(166.0 \mathrm{~kg} \mathrm{ha}^{-1}\right)$, high in phosphorus $\left(58.0 \mathrm{~kg}^{-}\right.$ $\left.{ }^{1}\right)$, and medium in potassium (167.0 $\left.\mathrm{kg} \mathrm{ha}^{-1}\right)$. The experiment was laid out in randomized block design with three replications. There were 13 treatments viz. of $\mathrm{T}_{1}-60 \mathrm{~cm}$ inter row spacings $+100 \% \mathrm{NPK}+$ mother shoot pruning (topping); $\mathrm{T}_{2}-45$ cmspacings $+100 \%$ $\mathrm{NPK}+$ topping; $\mathrm{T}_{3}-30 \mathrm{~cm}$ spacings $+100 \% \mathrm{NPK}+$ topping; $\mathrm{T}_{4}-60 \mathrm{~cm}$ spacings $+75 \% \mathrm{NPK}+$ topping + biofertilizer; $\mathrm{T}_{5}-45 \mathrm{~cm}$ spacings $+75 \% \mathrm{NPK}+$ topping + biofertilizer; $\mathrm{T}_{6}-30 \mathrm{~cm}$ spacings $+75 \% \mathrm{NPK}+$ topping + biofertilizer; $\mathrm{T}_{7}-60 \mathrm{~cm}$ spacings $+100 \% \mathrm{NPK}+$ no topping; $\mathrm{T}_{8}-45 \mathrm{~cm}$ spacings $+100 \% \mathrm{NPK}+$ no topping; $\mathrm{T}_{9}-30 \mathrm{~cm}$ spacings $+100 \% \mathrm{NPK}+$ no topping, $\mathrm{T}_{10}-60$ cm spacings $+75 \%$ NPK + no topping + biofertilizer; $\mathrm{T}_{11}$ - $45 \mathrm{~cm}$ spacings $+75 \% \mathrm{NPK}+$ no topping + biofertilizer; $\mathrm{T}_{12}-30 \mathrm{~cm}$ spacings $+75 \% \mathrm{NPK}+$ no topping + biofertilizer; $\mathrm{T}_{13}-$ Control (conventional planting of two budded setts).

The sugarcane chip bud seedlings of 30 days old were planted in rows with spacing of $80 \mathrm{~cm}$ and the intrarow spacings were maintained as per the treatment schedule. The topping of mother shoots was done on 45 days after planting as per treatments. Setts were treated with bio-inoculants mixture and applied as basal application@10kgha ${ }^{-1}$ mixed with 50 kg of decomposed farmyard manure. All other package of practices was uniformly adopted for all the treatment plots. The tiller numbers, cane length, cane girth, individual cane weight, millable canes, cane yield, commercial cane sugar (CCS \%) and sugar yield were recorded, statistically analysed.

\section{Results and Discussion}

\section{Effect on growth and yield components}

The adoption of $30 \mathrm{~cm}$ intra-row spacings for the chip bud raised sugarcane seedlings + topping + $100 \%$ of NPK $\left(\mathrm{T}_{3}\right)$ significantly registered maximum tillers $\left(2,02,800 \mathrm{ha}^{-1}\right)$ in first crop and $1,78,800 \mathrm{ha}^{-1}$ in ratoon crop as 90 days after planting (Table 1). The significant increase in tillers might be due to the higher number of seedlings per unit area, owing to closer intrarow spacings between the chip bud seedlings. Further, topping accelerated the tiller production, due to higher production of growth promoting substances. The application of 100 per cent NPK offers ample availability of essential nutrients facilitating effective utilization of nutrients for increased production of tillers. The results are in accordance with the observations of Loganathan et al. (2013). However, the $\mathrm{T}_{3}$ treatment was on par with the treatment $T_{9}$. Among the other treatments, $T_{10}$ had the lowest tiller population both in first crop plant $\left(1,58,200 \mathrm{ha}^{-1}\right)$ and ratoon $\left(1,65,000 \mathrm{ha}^{-1}\right)$ crop, which would be due to higher intra competition among the chipbud seedlings for agromanagements. The results arein agreement with the findings of Sulistiono et al. (2017).

There was significant enhancement in cane length (289 and $282 \mathrm{~cm})$, cane girth $(2.79$ and $2.66 \mathrm{~cm})$, individual cane weight $\left(2.06\right.$ and $\left.1.97 \mathrm{~kg}^{-1}\right)$ and millable canes $\left(1,27,600\right.$ and $\left.1,23,600 \mathrm{ha}^{-1}\right)$, respectively in plant and ratoon crop having $45 \mathrm{~cm}$ spacings $+100 \%$ of NPK + topping $\left(\mathrm{T}_{2}\right)$ treatment (Table 1). The appropriate agro techniques (spacing, nutrient supply, topping) might have helped plants in synthesizing the photosynthates in larger amount and thereby result in higher yield and yield attributes. The results were in accordance with the findings of Kasthuri (1996) and Raskar and Bhoi (2003). The $\mathrm{T}_{2}$ treatment was on par with $\mathrm{T}_{8}$ and $\mathrm{T}_{1}$. The minimum cane girth $(2.54$ and $2.38 \mathrm{~cm})$, individual cane weight $(1.67$ and $1.65 \mathrm{~kg})$ and millable cane population $\left(1,15,900\right.$ and $\left.1,08,700 \mathrm{ha}^{-1}\right)$ respectively, in plant and ratoon crop were assosiated with $30 \mathrm{~cm}$ spacing $+75 \%$ of 

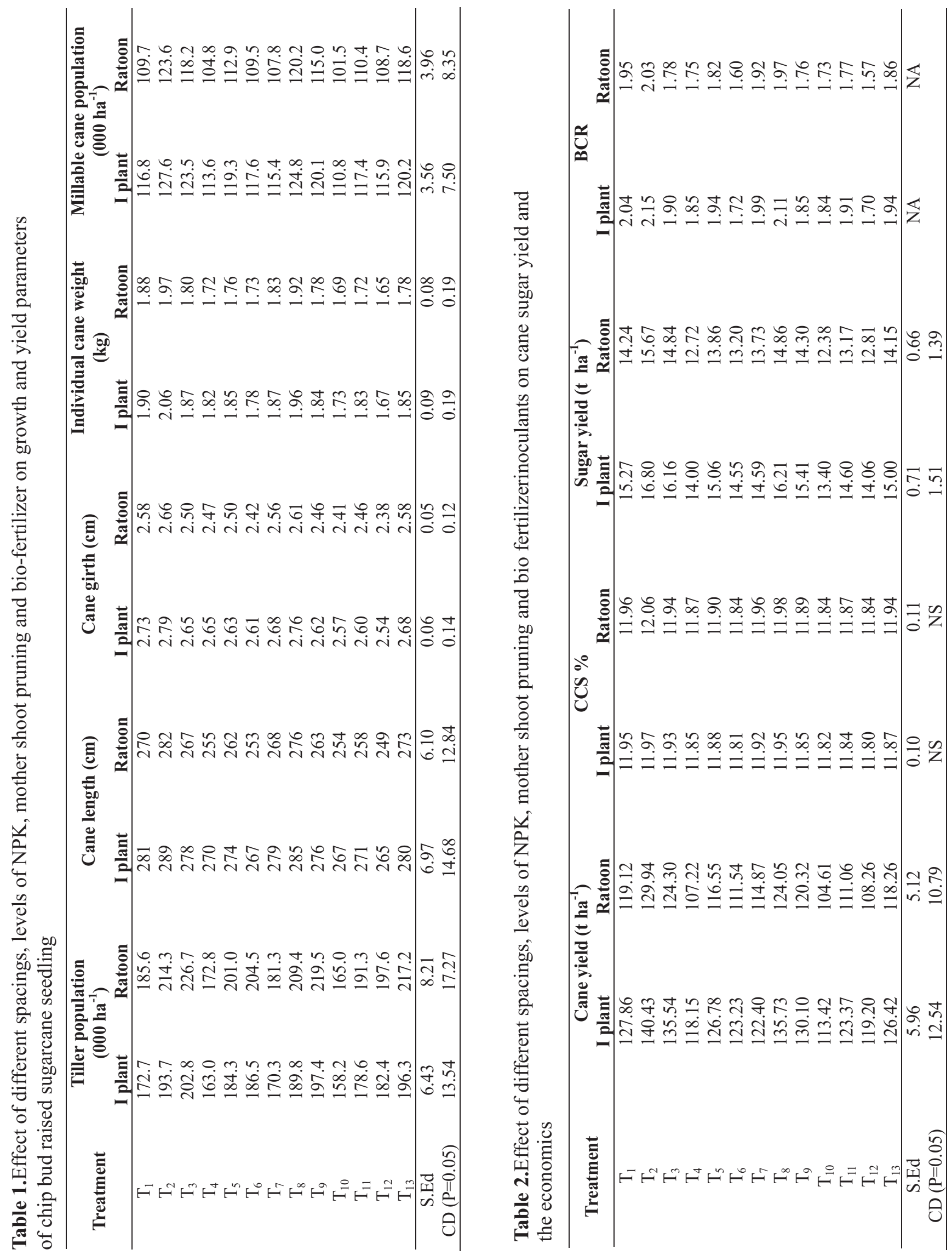
NPK + no topping + bio-inoculants $\left(T_{12}\right)$. Kathireson (2004) opined that inoculation of biofertilizer to sugarcane sets helps in higher productivity. The inter competitiveness between the chip bud seedlings and the profusely produced tillers for various input resources might have declined the yield parameters.

\section{Effect on juice quality}

Even though the adoption of $45 \mathrm{~cm}$ intra- row spacings for chipbud sugarcane seedlings + practice of topping along with $100 \%$ of NPK had maximum commercial cane sugar (CCS) values of 11.97 and 12.06 per cent, respectively (Table 2)in plant and ratoon crop but it was not significant.

\section{Cane and sugaryield}

The practice of planting sugarcane chip budded seedlings with $45 \mathrm{~cm}$ intra-row spacings and $100 \%$ recommended dose of NPK + topping $\left(\mathrm{T}_{2}\right)$ registered the maximum cane yield of 140.43 tha $^{-1}$ in plant crop and 129.94 tha $^{-1}$ in ratoon crop (Table 2). Shindeet al. (1999) also reported similar findings. The increase cane yield and CCS might have resulted in sugar yield with $\mathrm{T}_{2}$ treatment. The treatment $45 \mathrm{~cm}$ spacing $+100 \% \mathrm{NPK}$ + no topping also had comparable values for cane and sugar yields. Among the treatments, $60 \mathrm{~cm}$ spacings + $75 \%$ NPK + no topping + biofertilizer was associated with the lowest cane yield (113.42 and 104.61 tha $^{-1}$ ) respectively in plant and ratooncrop owing to the reduced yield parameters and CCS per cent .Kanjaneet al. (2007) also put similar views on reduced yield.

\section{Conclusion}

The practice of planting sugarcane chip budded seedlings with $45 \mathrm{~cm}$ intra-row spacing with optimal supply of 100 per cent recommended dose of NPK + topping was found to be the best method for achieving the maximum cane yield inplant and ratoon crop.

\section{References}

Kasthuri, K. (1996). Sugarcane- the poly bag way. Kissan World 23, 41-43.

Kabir, M.L., Saddiqui, S.A., Hossain, M.S., Alam, M.J., and Rahman, M.K. (2003).Comparative performance of different planting techniques of sugarcane. Progressive Agriculture 14, 7-9.

Kathireson, G. (2004). A review on use of bio-fertilizers on sugarcane production. Co-operative Sugar 35, 631-638

Kanjane, D., Pitchai, G.J., and Saravanan A. (2007). Effect of organic, inorganic and bio-fertilizer on soil nutrient availability in sugarcane (Co 86032) cultivation at Theni District of Tamil Nadu. Indian Sugarcane 56, 15-22.

Loganadhan, N., Biksham,Gujja, V. Vinod Goud., and Natarajan, V.S. (2013). Sustainable sugarcane Initiative (SSI): A methodology of "More with Less". Sugar Technology 15, 98-102.

Raskar, B.S., and Bhoi , P. G .(2003). Effect of Intra-row spacing, fertilizer levels and planting materials on yield and economics of pre-seasonal sugarcane under drip irrigation. Sugar Technology 5, 305-309.

Shinde, S.H., Dahiwalker S.D., and Berad, S.M. (1999). Influence of planting technique and fertilization through drip on yield, quality and economics of sugarcane. Journal of the Maharashtra Agricultural Universities 24, 276-278.

Sulistiono, Wawan, TaryonoPraptoYudono., and Irham(2017). Growth analysis of transplanted sugarcane bud chips seedling in the dry land. International Journal of Scientific and Technology Research 6, 109-120.

Received:December, 2017 Accepted: March, 2018 